\title{
On the identity of the tamarin AMNH 98303 ("Saguinus fuscicollis tripartitus"; Primates: Haplorrhini: Simiiformes: Platyrrhini: Callitrichidae)
}

\author{
Eckhard W. Heymann \\ Verhaltensökologie \& Soziobiologie, Deutsches Primatenzentrum, Leibniz-Institut für Primatenforschung, \\ Kellnerweg 4, 37077 Göttingen, Germany \\ Correspondence: Eckhard W. Heymann (eheyman@gwdg.de)
}

Received: 5 October 2021 - Revised: 20 December 2021 - Accepted: 21 December 2021 - Published: 24 January 2022

\begin{abstract}
The American Museum of Natural History houses the skin of a tamarin (AMNH 98303) labelled as Saguinus fuscicollis tripartitus. However, the specimen does not match the phenotype of this taxon, now named Leontocebus tripartitus, nor that of any other known species or subspecies of Leontocebus. In this note, we review past taxonomic revisions of the genus Saguinus - revisions that were largely driven by the contentious species or subspecies status of the golden-mantled saddleback tamarin S. fuscicollis tripartitus - and compare the phenotype of AMNH 98303 with those of other tamarins in the same genus to discuss the possible status of this specimen.
\end{abstract}

\section{Introduction: tamarin taxonomy and the status of the taxon tripartitus}

Tamarins are a diverse group of New World primates with a synonymic history of more than nine genera. All were placed in the genus Saguinus Hoffmannsegg by Hershkovitz (1977), but Rylands et al. (2016) separated out Hershkovitz's Saguinus nigricollis or white-mouthed tamarin group as belonging to the genus Leontocebus Lesson. Two species comprised Hershkovitz's S. nigricollis group (the black-mantled tamarin Saguinus nigricollis and the saddleback tamarin Saguinus fuscicollis), and Hershkovitz (1966, 1977) placed the golden-mantled saddleback tamarin S. fuscicollis tripartitus Milne-Edwards, 1878, as a subspecies of S. fuscicollis. Considered by Hershkovitz (1977) as a subspecies, Thorington (1988) elevated $S$. fuscicollis tripartitus to species rank, Saguinus tripartitus, based on an alleged sympatry with Saguinus fuscicollis lagonotus. Evidence for this sympatry is, however, absent or at best very weak (reviewed in Rylands et al., 2011). In 2000, I indicated that the lack of evidence for sympatry between the two tamarins meant that tripartitus should be downgraded to a subspecies or that the 13 of the 14 subspecies of S. fuscicollis of Hershkovitz (1977) consid- ered valid at the time be considered species ${ }^{1}$. Molecular studies subsequently revealed that $S$. fuscicollis tripartitus clusters in a clade comprising several subspecies of $S$. fuscicollis (Matauschek et al., 2011; Buckner et al., 2015), which would have made this clade paraphyletic if the species status of $S$. fuscicollis tripartitus or the subspecies status of the other taxa were retained. Finally, this led to a taxonomic revision that resulted in two major changes (Rylands et al., 2016): (1) separation of the small tamarins of Hershkovitz's (1977) S. nigricollis group as a genus of its own, Leontocebus; (2) elevation of most subspecies of the former species $S$. fuscicollis to species rank.

\section{The specimen AMNH 98303 and why it cannot be S. fuscicollis tripartitus}

The American Museum of Natural History houses a number of skins of tamarins, amongst them several labelled as Saguinus fuscicollis tripartitus, one of them being AMNH 98303. However, this specimen contrasts very strongly with the other S. fuscicollis tripartitus specimens (Fig. 1a, b): it

\footnotetext{
${ }^{1}$ In 1996, Peres et al. showed that Saguinus fuscicollis acrensis was a hybrid.
} 


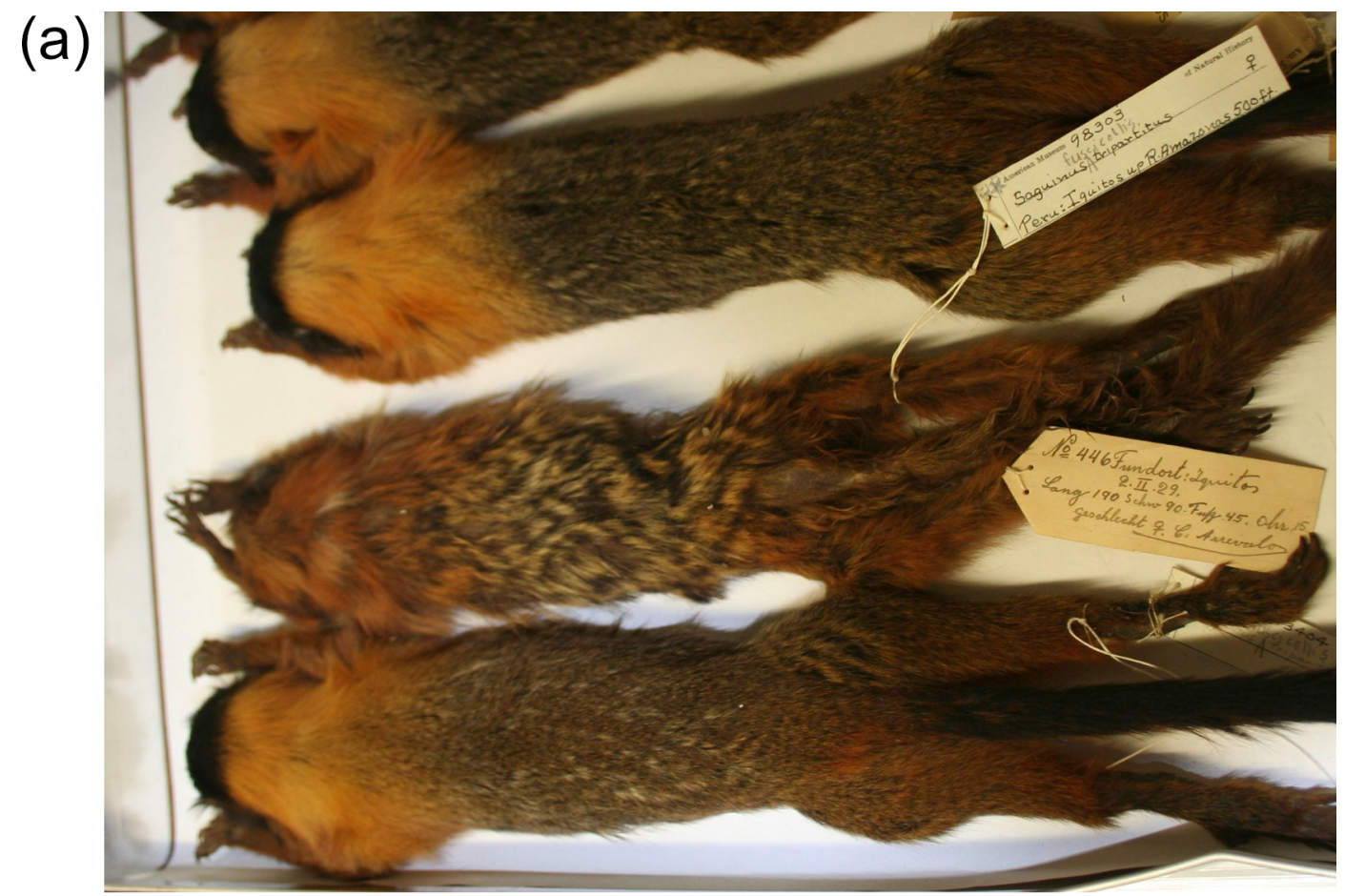

(b)

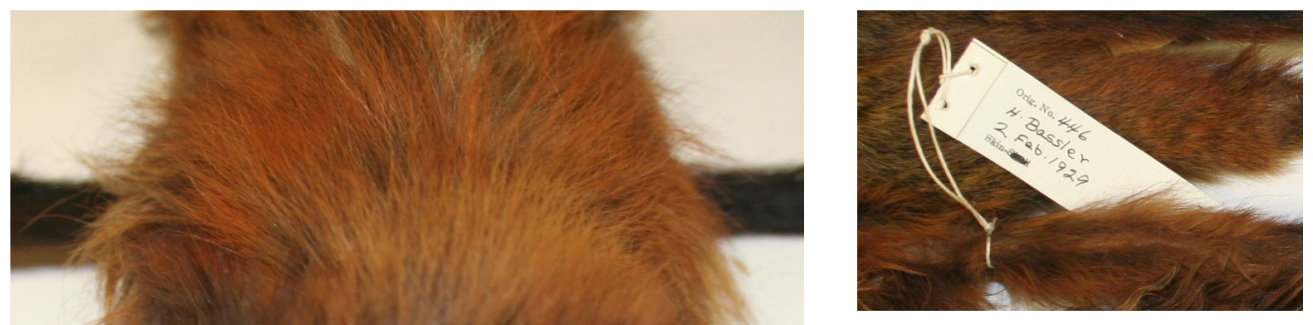

(c)

Figure 1. (a) Specimens of Saguinus fuscicollis tripartitus (above and below) and the doubtful specimen AMNH 98303 (centre). (b) Frontal view of AMNH 98303. (c) Backside of the tag. Photos: Christian Matauschek. 
lacks the black forehead and face; the neck is not uniformly orange-golden but rather reddish-brownish; and the back ("saddle") shows the typical agouti pattern of most members of the S. nigricollis group of Hershkovitz (1977). According to the original label tagged to the specimen, it is a female found (German Fundort: place where found) in Iquitos by C. Arrevalos on 29 February 1929 (Fig. 1a). A second label, carrying the name $\mathrm{H}$ [arvey] Bassler ${ }^{2}$, also quotes Iquitos (Fig. 1a, c). The range of the golden-mantled tamarin is restricted to the interfluvium between the rivers Napo and Curaray, while Iquitos is located on the Amazon below its confluence with the Napo; Iquitos can, therefore, only be the place where the tamarin was obtained, probably purchased, by the collector, and not the place of origin.

The phenotype of AMNH 98303 does not match any other species or subspecies of Leontocebus in the region around Iquitos (Leontocebus nigricollis graellsi, Leontocebus nigricollis nigricollis, Leontocebus lagonotus, Leontocebus nigrifrons, Leontocebus illigeri, Leontocebus fuscicollis fuscicollis) or any other Peruvian member of the genus (Leontocebus leucogenys, Leontocebus weddelli melanoleucus, Leontocebus weddelli weddelli; see Aquino et al., 2015, and Fig. 1 in Rylands et al., 2016). Superficially, it shows similarity to Leontocebus cruzlimai, mainly because of the overall reddish colouration as shown in Rylands et al. (2016: Fig. 1) and da Cruz Lima (1945: Plate 38, Fig. 3a). However, the drawings may not be representative of its phenotype; a photo of a living animal in Sampaio et al. (2015), Fig. 4, does not show the bright reddish colouration. Also, AMNH 98303 lacks the white frontal blaze above the eyes, although this is probably a variable trait. It occurs in some individuals of L. lagonotus, a species that otherwise lacks it, being present in some AMNH specimens (Voss and Fleck, 2011) and also observed in the wild (Christian Matauschek, personal communication, 2008). Finally, L. cruzlimai is distributed in Brazil between the rivers Purus and Pauini, a considerable distance from Iquitos, making it unlikely (but not impossible) that the animal was taken to Iquitos from there.

With a head-body length (assuming that the German word Lang on the label refers to Länge, meaning length) of $190 \mathrm{~mm}$, AMNH 98303 is not a fully grown adult. Adults of other Leontocebus taxa range from 223 to $232 \mathrm{~mm}$ (Rylands et al., 2011; see also measurements in Hershkovitz, 1977). Since there is no evidence in other tamarin species for colouration changes during ontogeny, except for the area around the mouth during the transition from infant to juvenile (Eckhard W. Heymann, personal observations), and since the

\footnotetext{
${ }^{2}$ Harvey Bassler worked as chief geologist for Standard Oil from 1921 to 1931 in Peru, with Iquitos being his headquarters (Myers, 2000). During his expeditions in Peruvian Amazonia, he mainly collected amphibians and reptiles, but also some mammals. These collections went to the American Museum of Natural History for which Bassler worked as a research associate at the Department of Herpetology from 1932 onward (Myers, 2000). No information could be found on C. Arrevalo (perhaps a misspelling of Arevalo).
}

measurement indicates that the specimen was approaching adulthood, the possibility can be excluded that it had not yet reached "adult colouration". It therefore differs from $S$. fuscicollis tripartitus and all other recognized white-mouthed $S$. nigricollis group tamarins.

\section{AMNH 98303: hybrid or unknown species?}

Could AMNH 98303 be a hybrid between different Leontocebus species? Tamarins are known to hybridize in captivity and in the wild (Hershkovitz, 1977; Peres et al., 1996). At this point it is interesting to note that Encarnación et al. (1990) reported S. fuscicollis tripartitus from the south bank of the Río Yuvineto, a right-bank tributary of the Río Putumayo, where it would be sympatric with $L$. nigricollis graellsi. The second half of his description coincides neither with $S$. fuscicollis tripartitus nor with AMNH 98303: "Esta subespecie es fácilmente diferenciable del $S$. fuscicollis nigrifrons por la presencia de la pequeña bifurcación blanca frontal y color agutí intenso de la mitad posterior del cuerpo" (p. 75; "This subspecies can be easily distinguished from $S$. fuscicollis nigrifrons by the presence of a small white frontal bifurcation and the intensive agouti colouration of the posterior half of the body"). But it does also not coincide with the phenotypes of $L$. nigricollis graellsi and L. nigricollis nigricollis, whose ranges are parapatric around the area of the Putumayo-Napo interfluvium mentioned by Encarnación et al. (1990) for S. fuscicollis tripartitus.

The possibility should not be excluded that AMNH 98303 is an undescribed taxon. Despite a long history of primatological field explorations and collections, 124 new primate species have been described since 1990, 32 of them from the neotropics (Mittermeier and Rylands, 2021), having either been newly discovered in the wild or re-described through examination and genetic analyses of existing museum specimens.

In conclusion, AMNH 98303 is not Leontocebus tripartitus. Its real taxonomic status will remain unresolved until pertinent genetic analyses are undertaken. For comparison, mtDNA sequences are available for a large number of Leontocebus taxa (Matauschek et al., 2011; Buckner et al., 2015; Sampaio et al., 2015). Stable isotope analyses could also help to explore its geographic origin (Koehler et al., 2019; Dominy et al., 2020). Also, other museums could revise their tamarin collections to see whether they include specimens that phenotypically match AMNH 98303.

This note underlines the value of museum collections for exploring the diversity of life and shows that we are still far from knowing this diversity even in an otherwise rather wellknown taxon such as primates. 
Data availability. No data sets were used in this article.

Competing interests. The contact author has declared that there are no competing interests.

Disclaimer. Publisher's note: Copernicus Publications remains neutral with regard to jurisdictional claims in published maps and institutional affiliations.

Acknowledgements. I am grateful to my former $\mathrm{PhD}$ student Christian Matauschek for providing the photos, to Robert S. Voss from the American Museum of Natural History for information about Harvey Bassler, and to Anthony B. Rylands for helpful comments that strongly improved the paper.

Review statement. This paper was edited by Augusto Vitale and reviewed by Anthony B. Rylands.

\section{References}

Aquino, R., Cornejo, F. M., Cortés Ortiz, L., Encarnación, C. F., Heymann, E. W., Marsh, L. K., Mittermeier, R. A., Rylands, A. B., and Vermeer, J.: Monkeys of Peru, Pocket identification guide, Tropical Pocket Guide Series, Conservation International, Arlington, 2015.

Buckner, J. C., Lynch Alfaro, J. W., Rylands, A. B., and Alfaro, M. E.: Biogeography of the marmosets and tamarins (Callitrichidae), Mol. Phylogenet. Evol., 82, 413-425, 2015.

da Cruz Lima, E.: Mammals of Amazonia 1, General introduction and Primates, Museo Paraense Emilio Goeldi de Historia Natural e Etnografia, Belém, Rio de Janeiro, 274 pp., 1945.

Dominy, N. J., Ikram, S., Moritz, G. L., Wheatley, P. V., Christensen, J. N., Chipman, J. W., and Koch, P. L.: Mummified baboons reveal the far reach of early Egyptian mariners, eLife, 9, e60860, https://doi.org/10.7554/eLife.60860, 2020.

Encarnación, F., Castro, N., and de Rham, P.: Observaciones sobre primates no humanos en el río Yuvineto (río Putumayo), Loreto, Perú, in: La Primatología en el Perú. Investigaciones Primatológicas (1973-1985), edited by: Castro-Rodríguez, N. E., Imprenta Propaceb, Lima, 68-79, 1990.
Hershkovitz, P.: Taxonomic notes on tamarins, genus Saguinus (Callithricidae, Primates) with descriptions of four new forms, Folia Primatol., 4, 381-395, 1966.

Hershkovitz, P.: Living New World Monkeys (Platyrrhini), Vol. 1, University of Chicago Press, Chicago, ISBN 0226327884, 1977.

Koehler, G., Kardynal, K., and Hobson, K.: Geographical assignment of polar bears using multi-element isoscapes, Scientific Reports, 9, 9390, https://doi.org/10.1038/s41598-019-45874-w, 2019.

Matauschek, C., Roos, C., and Heymann, E. W.: Mitochondrial phylogeny of tamarins (Saguinus, Hoffmannsegg 1807) with taxonomic and biogeographic implications for the S. nigricollis species group, Am. J. Phys. Anthropol., 144, 564-574, 2011.

Mittermeier, R. A. and Rylands, A. B.: New primates described from 1 January 1990 to 1 September 2021, available at: http: //www.primate-sg.org/new_species, last access: 20 December 2021.

Myers, C. W.: A history of herpetology at the American Museum of Natural History, B. Am. Mus. Nat. Hist., 252, 1-232, 2000.

Peres, C. A., Patton, J. L., and da Silva, M. N. F.: Riverine barriers and gene flow in Amazonian saddle-back tamarins, Folia Primatol., 67, 113-124, 1996.

Rylands, A. B., Matauschek, C., Aquino, R., Encarnación, F., de la Torre, S., Heymann, E. W., and Mittermeier, R. A.: The range of the golden-mantle tamarin, Saguinus tripartitus (Milne Edwards, 1878): distributions and sympatry of four tamarin species in Colombia, Ecuador, and northern Peru, Primates, 52, 25-39, 2011.

Rylands, A. B., Heymann, E. W., Lynch Alfaro, J., Buckner, J. C., Roos, C., Matauschek, C., Boubli, J. P., Sampaio, R., and Mittermeier, R. A.: Taxonomic review of the New World tamarins (Primates: Callitrichidae), Zool. J. Linn. Soc.-Lond., 177, 10031028, 2016.

Sampaio, R., Röhe, F., Pinho, G., de Sousa e Silva-Júnior, J., Farias, I., and Rylands, A.: Re-description and assessment of the taxonomic status of Saguinus fuscicollis cruzlimai Hershkovitz, 1966 (Primates, Callitrichinae), Primates, 56, 131-144, 2015.

Thorington, R. W.: Taxonomic status of Saguinus tripartitus (Milne-Edwards, 1878), Am. J. Primatol., 15, 367-371, 1988.

Voss, R. S. and Fleck, D. W.: Mammalian diversity and Matses ethnomammalogy in Amazonian Peru, Part 1, Primates, B. Am. Mus. Nat. Hist., 351, 1-81, 2011. 